\title{
Measuring and Eliminating Corruption through Strengthening Legal Structures
}

\author{
Wahdah Zainal Imam \\ Faculty of Law, Khairun University, North Maluku, Indonesia \\ Phone: +62-921-3123368 E-mail: wahdahzimam@gmail.com
}

\begin{abstract}
Corruption has become a widespread reality in the life of people, such as bribery to misuse the wealth of country for personal and group interests. Even so, in the reality as occurs that much economic development is delayed due to corruption, collusion and nepotism for development projects both in central and regional governments. The research is a juridical-normative research by using statute, case, historical, comparative and conceptual approaches. The processing and analysis of legal materials was aimed to find pragmatic truth and/or coherence. The results show that restructuring of institutional must also be based on empirical needs. This empirical need is a consequence of the dynamics of development that occur in society along with various demands for ever increasing needs. With the emergence of a variety of new needs and the development of existing needs, organizational and institutional restructuring is needed to meet the demands of the era. Hence, it is recommended to strengthen the legal standing of the Public Prosecution institution as a law enforcement institution at the legislation levels so that the eradication of corruption can be optimized and realize good and clean governance.
\end{abstract}

Keywords: Corruption; Legal Structure; Legal System; Public Prosecution

DOI: $10.7176 / \mathrm{JAAS} / 59-06$

Publication date: December $31^{\text {st }} 2019$

\section{Introduction}

In the life of society, nation and State, absolutely it is necessary to regulate the relationship between citizens and the State. Law cannot only be viewed as textual and permanent, it is existing to regulate society and not vice versa. For this reason, law should be dynamic in the sense that in the development of the community, the law must be able to follow the development of a country. ${ }^{1}$ Corruption has become a widespread reality in the life of people, such as bribery to misuse the wealth of country for personal and group interests. In the reality as occurs that much economic development is delayed due to corruption, collusion and nepotism for development projects both in central and regional governments.

A legal problem that often occurs in Indonesia and requires extra treatment is corruption. In Indonesia, corruption case continues to increase, both in terms of the role of the corruptor, their position, amount of State's losses, and even the role of their family or colleagues. Although there have been many slogans and socialization about the dangers of corruption, both in government and educational institution, it apparently does not affect the resolution and the handling of corruption by law enforcers to minimize the corruption. Ultimately, this condition can affect the economic development and budget absorption both central and regional government.

Brasz $^{2}$ argues that corruption can be categorized as power without the rule of law. Therefore, there is always a presumption of the use of power to achieve a goal other than the goals listed in the transfer of power. Many public servants consider important the power as the money. This view has given an outline that the scope of corruption is within the environment of power or authority or position relating to the economy or project development.

Actually, a change of power from centralization to decentralization in the form of local autonomy has created new problems where corruption moves from the center to the region. With various modus operandi,

\footnotetext{
${ }^{1}$ Purwanti, A., Ispriyarso, B., \& Wijaningsih, D. (2018). Strategizing Local Regulation On Women Representation in Village Policy-Making as A Realization of Sustainable Development Goals: A Study in Semarang Regency. Journal of Social Studies Education Research, 9(4), 319-333.

${ }^{2}$ Kimberly Ann Elliot. 1999. Korupsi dan Ekonomi Dunia. Jakarta: Yayasan Obor Indonesia. p. 182.
} 
corruption is good covered that sometimes in the name of policy. ${ }^{1}$ Corruption in the name of public policy, whether issued by legislative, executives, or decision-making institutions in State- and Regional Owned Enterprises and banking is a modus operandi of corruption or non-conventional crime. ${ }^{2}$

In development, the Indonesian government cooperates with the community based on the principle of empowerment and community participation so that if the government needs goods, the government implements it through the procurement of goods and services. In the procurement of government goods and services, it is susceptible to corruption, collusion and nepotism. The public prosecution as one of the law enforcement institutions ${ }^{3}$ plays an important role in responding government policies in resolving the problem of budget absorption and accelerating national development, even though the public prosecution has a role as an investigator in the eradication of corruption. This means that the public prosecution in handling and resolving corruption has a role as taking act.

\section{Method of the Research}

The research is a juridical-normative research by using statute, case, historical, comparative and conceptual approaches. ${ }^{4}$ The processing and analysis of legal materials was aimed to find pragmatic truth and/or coherence. This processing and analysis is very substantial in legal research because they are prescriptive nature.

\section{Structural Strengthening for Eliminating Corruption: Legal System Review}

The role of law enforcement agencies in eradicating corruption in Indonesia is very large and significant. An institution that plays an active role in efforts to eradicate corruption in Indonesia is the public prosecution. In this context, the public prosecution has conducted a number of reforms and programs in effort to deal with corruption, one of them is the establishment of legal structure by the attorney general which has encouraged development acceleration and increased anti-corruption awareness.

Related with various corruption, according to Jeremy Pope ${ }^{5}$ argued that efforts that can be done are by increasing national integrity. Introducing this national integrity system in all layer of community is very important for the reform process and should be conducted continuously. This approach is important so that development goals can be achieved.

For the author, if the government through the public prosecution is serious in eradicating corruption, then the involvement of the public prosecution. As mentioned earlier, it can be understood that the involvement can begin from the stages of planning, auction, implementation, supervision, licensing, procurement of goods and services, orderly administration and management of State finances. For this reason, the public prosecution can be actively involved at every stage of the implementation of government and development activities. Specifically, for the stage of planning, on the basis that planning is the prerogative of the government, State-Owned Enterprises (BUMN), Regional-Owned Enterprises (BUMD), then the involvement of the public prosecution at this stage is only coordinating. It means that the public prosecution with the government and BUMN/BUMD coordinate and communicate programs that have been specified in development planning.

In this context, the author believes that in the implementation of development, particularly in the procurement of government goods and services or the implementation of other government projects, the public prosecution should be involved at every stage of the activity even without the request of the relevant agency. It is intended the implementation of development is really well-supervised so that corrupt behavior or deviations from certain parties can be prevented as early as possible. That way, efforts to eradicate crime, especially corruption can be properly addressed and even prevented as early as possible.

\footnotetext{
${ }^{1}$ Rohim. 2008. Modus Operandi Tindak Pidana Korupsi. Cimanggis Depok: Pena Mukti Media. p.17.

2 Ridwan HR. 2003. Hukum Administrasi Negara. Yogyakarta: UII Press. p. 80.

${ }^{3}$ Bell, John. "Legal Means for Eliminating Corruption in the Public Service." In General Reports of the XVIIth Congress of the International Academy of Comparative Law. Bruylant, Brussels, pp. 785-807. 2007.

${ }^{4}$ Peter Mahmud Marzuki. 2009. Penelitian Hukum. Jakarta: Kencana. p. 93.

${ }^{5}$ P.A.F. Lamintang, et.al. 1990. Hukum Pidana Indonesia, cet. Ke-III. Bandung: Sinar Baru. pp. 231-234.
} 
Unlike the case in guarding and securing the implementation of the administration, for this activity it must be preceded by a letter of request from the relevant-agencies because the public prosecution cannot necessarily interfere in the affairs of other institutions. In this context, the public prosecution is as a "legal consultant" for the government, State-Owned Enterprises (BUMN), Regional-Owned Enterprises (BUMD) which if there are problems in conducting their duties, the public prosecution as a place of consultation.

Build infrastructure like build the future of a civilization. Through accelerating infrastructure development evenly throughout the country, it is expected to create strong connectivity between regions. Surely, it is to reduce logistics costs, inequality, improve the quality of life of the people, and eliminate economic disparities between regions in Indonesia. One of the benefits that can be felt immediately is increasing level in several economic indicators. Policy reforms to encourage the acceleration of infrastructure have raised the position of competitiveness, logistical performance and easiness to making business. ${ }^{1}$

According to the 2018 World Bank Group's report, the competitiveness of Indonesia's infrastructure was $52^{\text {nd }}$ position in 2018; it is improved compared to $70^{\text {th }}$ position in 2010-2013. Then, the logistics performance index which takes into account aspects of infrastructure support for logistics has also increased from a range of 2.7 in 2010 to 3.1 in 2018. Also, the working on the National Strategic Project has opened up employment opportunities. To complete all national strategic projects, the estimated total workforce needed reaches 394.000 (three hundred ninety four thousand). The most needed of labor by national strategic projects is vocational education and polytechnic graduates. It is just the direct-labor, not including the absorption of indirect labor which is a multiplier effect of national strategic projects. ${ }^{2}$

For long-term, based on a study conducted by Tusk Advisory in 2018, the development of infrastructure, especially national strategic project development is predicted to have an impact on Gross Domestic Product (GDP) growth of $7.2 \%$ in 2023 and $9.3 \%$ in 2030. In his study also stated that the development will create economic equality that marked by a decrease in Gini Coefficient ${ }^{3}$ by 3 points and will reduce poverty by up to $14.9 \%$. All of this can be realized by assuming all national strategic projects have been completed and operating in a suitable and timely manner.

For the moment, the government is optimizing budget allocations in infrastructure development projects to encourage regional growth centers. The infrastructure development is focused on 35 (thirty five) Strategic Development Areas, which have been established as the basis for integrated PUPRs infrastructure planning and programming to improve competitiveness and reduce disparity between regions. One such development is the development of border areas through the construction of parallel border roads to support the economy of the people in the foremost regions of the country. In addition, development at the border area will also strengthen national unity and integrity and strengthen national defense and security, as well as to increasing the economic activities of the local community. ${ }^{4}$

In economic analysis, the infrastructure can increase public access to resources so that it can increase productivity and efficiency and ultimately can increase economic growth. Economic growth is one indicator to see the development result that has been done and also useful to determine the direction of development in the future. Positive economic growth shows an increase in the economy. ${ }^{5}$

In relation with the theory of economic analysis of law as initiated by Richard A. Posner which emphasizes the importance of efficiency in legal development, then maximizing available resources can encourage growth and increase people's welfare. For this reason, in the era of modernization and globalization, access to resources needs to be opened as wide and as wide as possible in order to be able to access existing

\footnotetext{
${ }^{1}$ Coordinating Ministry for Economic Affairs of the Republic of Indonesia, Mendorong Pertumbuhan Ekonomi Melalui Infrastruktur. Source: https://www.ekon.go.id/berita/view/mendorong-pertumbuhan-ekonomi.4321.html, accessed on 14 August 2019.

${ }^{2}$ Ibid

${ }^{3}$ Gini Coefficient or Gini Ratio is a tool to measure the degree of inequality in population distribution. It is a measure of aggregate inequality (as a whole) its numbers range from zero (perfect equalization) to one (perfect inequality). Source: https://www.dictio.id/t/apakah-yang-dimoted-with-kofficient-gini/8371, accessed August 14, 2019

${ }^{4}$ Ministry of Finance of Republic of Indonesia. Percepatan Pembangunan Infrastruktur Pacu Pertumbuhan Ekonomi. Source: https://www.kemenkeu.go.id/publikasi/berita/percepatan-pembangunan-infrastruktur-pacu-pertumbuhan-ekonomi/. Accessed on 14 August 2019.

${ }^{5}$ Quoted from 2015 Report of PT. Jasa Marga (Persero), Tbk. Mewujudkan Infrastruktur Untuk Mempercepat Pertumbuhan Ekonomi Nasional. Report in 2015.
} 
resources

In order to realize the welfare of the peoples, the government needs to maximize every effort in order to meet the needs of the peoples, both through legislation instrument and through good natural resource management activities. Legislative instruments are needed to reduce the dominance of certain groups or even foreign parties in natural resource management. In this natural resource management activity the government must actively involve the community as the principle of an empowering state where everything is delivered to the peoples and the State only facilitates. ${ }^{1}$

One effort of the government to open access to existing resources is to maximize infrastructure development. Build infrastructure can make it easier for governments and communities to protect the resources, especially natural resources. In the national development, the government has set a number of national strategic projects which all need to be monitored, guarded, and properly secured so that these projects can run-well and meet the expectations of all parties. By doing so, it is hoped that the implementation of this national strategic project will be effective and efficient for improving people's welfare.

Eradicating corruption in Indonesia is not only through the sanction to corruptors, but it can also be taken a better way through preventive measure in order to cut down corruption. To run a program to minimize corruption with a preventive measure, the President of the Republic of Indonesia issued a Presidential Instruction No. 7 of 2015 concerning the Prevention Measure and Eradicating Corruption. Specifically, in the implementation of government projects, the Public Prosecution institution should be involved at every stage of the activity even without the request of the relevant-agency. This is intended for the implementation of development is really well-supervised so that corrupt behavior or deviations from certain parties can be prevented as early as possible. As well as, the government in implementing development can feel safe. If there are legal issues, the government can request legal enlightenment directly from the Public Prosecution.

In principle, restructuring the public prosecution institution is not easy, although empirically it is needed. The problem is the duties and functions of the public prosecution institution itself. For the author, restructuring of the public prosecution institution is very necessary based on the thought to change the paradigm of the public prosecution institution. So far, the public prosecution is seen only as a law enforcement agency that conducts law enforcement activities.

As described above, the author can emphasize that the position, function, duties and authority of the public prosecution are actually conducting law enforcement activities and it is classified as repressive measures. Practically, it can also be seen that the public prosecution as a law enforcement institution conducts enforcement activities based on requests from applicants, both the public and the government. The public prosecution is the State' representative to provide legal protection to the public through the prosecution and other authorities granted to them.

In general, the authors consider that the duties, functions, and authority of the public prosecution as a law enforcement institution not only conducting repressive measures, but also preventive. ${ }^{2}$ For the author, it is necessary to choose the focus of activities in the fields that exist in the public prosecution institution, namely there are fields that focus on actions of enforcement or law enforcement (repressive) and there are areas that focus on preventive actions (preventive). This is intended so that the focus of the field on its duties and authority is not divided.

If related to the process of guarding and securing government and development, the public prosecution

\footnotetext{
${ }^{1}$ Muhammad Ilham Arisaputra. 2015. Agrarian Reform in Indonesia. Jakarta: Sinar Grafika. p. 96. In this book explained that government intervention is more focused on efforts to improve social welfare and justice so that it is expected that there will be a significant increase in sustainable welfare with the volume of interference given in the law. Through this approach, the community is given the broadest possible participation to determine for themselves what is best for them. While, the government is obliged to accommodate and facilitate the interests of the community in order to improve their welfare. In empowering states, the State continues to strive for general prosperity and social justice, but the ways taken to achieve these goals no longer use a centralized approach, but rather refers to efforts to stimulate the creativity of the community, so that people take the initiative, initiative and creativity, while the government facilitates and makes policies that accommodate the interests of the public at large.

${ }^{2}$ Hendrik Dengah, M. Syukri Akub, Slamet Sampurno, Syamsuddin Muchtar. (2019). 'Hand Catch Operation' on Corruption Crimes: The Case of the KPK in Indonesia, Journal of Law, Policy and Globalization, Vol. 81, pp: 32
} 
institution is currently considered passive in the sense that the public prosecution through TP4 can only work if there is a request from the relevant institution for government and development guarding and security. Not to mention if looking at the flow of bureaucracy and complicated administration and several other obstacles as described previously that make the role of the public prosecution becomes not optimal to oversee and secure government and development. Depart from that, the author thinks an ideal institutional model for combating crime, and in this case is corruption.

Institutionally, the establishment of this new instrument will be able to maximize the performance of government and development guarding and security because the public prosecution is no longer passive by waiting for requests or proposals, but it can actively conducts their duties through coordination mechanisms with related parties, namely the government (central and local), State-Owned Enterprises (BUMN), and Regional-Owned Enterprises (BUMD). The working mechanism of this instrument can begin after the completion of the planning stage in government agencies, State-Owned Enterprises (BUMN), and Regional-Owned Enterprises (BUMD). At the planning stage, the public prosecution does not need to be included because the working and development planning is a full-authority for government agencies, StateOwned Enterprises (BUMN), and Regional-Owned Enterprises (BUMD). The results of this planning stage are conveyed to the public prosecution so that they can analyze and determine the working steps needed to fulfill their duties and authority. By the eradicating of corruption, it is expected the welfare of peoples can improve. In addition, through this pattern it is expected a good and clean bureaucratic culture and free from corruption, collusion and nepotism.

\section{Conclusion}

Corruption cases in Indonesia continues to increase, both in terms of the role of the corruptor, their position, amount of State's losses, and even the role of their family or colleagues. Although there have been many slogans and socialization about the dangers of corruption, both in government and educational institution, it apparently does not affect the resolution and the handling of corruption by law enforcers to minimize the corruption. The institutional structuring and restructuring is done by considers the reinventing government which contains ten principles in implementing changes in government. Restructuring of institutional must also be based on empirical needs. This empirical need is a consequence of the dynamics of development that occur in society along with various demands for ever increasing needs. With the emergence of a variety of new needs and the development of existing needs, organizational and institutional restructuring is needed to meet the demands of the era. Hence, it is recommended to strengthen the legal standing of the Public Prosecution institution as a law enforcement institution at the legislation levels so that the eradication of corruption can be optimized and realize good and clean governance.

\section{References}

Annual Report of PT. Jasa Marga (Persero), Tbk. Mewujudkan Infrastruktur Untuk Mempercepat Pertumbuhan Ekonomi Nasional. Report in 2015.

Asep N. Mulyana, 2016. Dimensi Koruptif Kebijakan (Pejabat) Publik, Jakarta: Madju Press.

Bell, John. "Legal Means for Eliminating Corruption in the Public Service." In General Reports of the XVIIth Congress of the International Academy of Comparative Law. Bruylant, Brussels, pp. 785-807. 2007.

Hendrik Dengah, M. Syukri Akub, Slamet Sampurno, Syamsuddin Muchtar. (2019). 'Hand Catch Operation' on Corruption Crimes: The Case of the KPK in Indonesia, Journal of Law, Policy and Globalization, Vol. 81, pp: 32

Kimberly Ann Elliot. 1999. Korupsi dan Ekonomi Dunia. Jakarta: Yayasan Obor Indonesia.

P.A.F. Lamintang, et.al. 1990. Hukum Pidana Indonesia, cet. Ke-III. Bandung: Sinar Baru. pp. 231-234.

Peter Mahmud Marzuki. 2009. Penelitian Hukum. Jakarta: Kencana. 
Purwanti, A., Ispriyarso, B., \& Wijaningsih, D. (2018). Strategizing Local Regulation On Women Representation in Village Policy-Making as A Realization of Sustainable Development Goals: A Study in Semarang Regency. Journal of Social Studies Education Research, 9(4), 319-333.

Ridwan HR. 2003. Hukum Administrasi Negara. Yogyakarta: UII Press.

Rohim. 2008. Modus Operandi Tindak Pidana Korupsi. Cimanggis Depok: Pena Mukti Media.

Sugeng Purnomo, Muhadar, Farida Patittingi, and M. Said Karim. (2018). Corruption Crime in Lending to the Government Banks: A Challenge in Criminal Law, Journal of Law, Policy and Globalization, Vol. 80 . 